\title{
TOKUSUKE UTSUGI'S SEXUAL MASOCHISM IN JUNICHIRO TANIZAKI'S DIARY OF A MAD OLD MAN
}

\author{
Abdul Muhid dan Meria Zakiah Alfisuma
}

\author{
Email: abdmuhid@sunan-ampel.ac.id, abd_muhid050275@yahoo.com \\ Fakultas Psikologi IAIN Sunan Ampel Surabaya \\ Alamat Korepondensi: Jalan A. Yani 117 Surabaya
}

\begin{abstract}
This paper discussed one of the sexual disorders called sexual masochism through literary study. By discussing one of the novels by Junichiro Tanizaki entitled Diary of a Mad Old Man, the writers have some objectives in writing this paper. First, to describe sexual masochism experienced by Tokusuke Utsugi through the symptoms reflected on his behavior and way of thinking. Second, to uncover the causal factor and the impact of Tokusuke Utsugi' sexual masochism in Junichiro Tanizaki's Diary of a Mad Old Man. This study uses descriptive qualitative methods; all of the data are obtained by doing library research (literature review). The analysis result shows Tokusuke Utsugi was a sexual masochist, ie man who has sexual deviations by symptoms experienced such as 1) Tokusuke Utsugi's sexual desire resulting from torture or acceptance of pain from Satsuko, 2) Tokusuke Utsugi's sexual desire resulting from suffering due to his various illnesses, 3) Tokusuke Utsugi's sexual desire resulting from the insult he received from Satsuko. Sexual masochism suffered by Tokusuke Utsugi is the result of burial deviant sexual fantasies. As a result of the fulfillment of a deviant sexual desire, he was willing to do crazy things to satisfy his sexual desire.
\end{abstract}

\section{Keywords}

Tokusuke, Sexual Masochism

\section{Introduction}

Psychology and literature have strong links each other because psychology can be used to clarify or explain scientifically about the various problems which are reflected in literature; by contrast, works of literature is one way to introduce some of the problems associated with psychology. In this paper, the writers are interested in analyzing novel as one of literary works which involve behavior and character of human being to present knowledge into psychology.

Sexual masochism is one example of abnormal psychology. According to George, sexual masochism is one type of paraphilia on sexual deviations. Most of the sexual masochists are male. While the object is being hurt of people with sexual masochism is the people itself (www.medicastore.com). Diary Of A Mad Old Man by Junichiro Tanizaki has a theme of sexual deviation, especially about sexual masochism experienced by the main character, Tokusuke Utsugi. Based on the above description, the writers hope by discussing sexual masochism through literary study will help the readers understand this kind of sexual disorder deeply.

\section{Literature and Psychology}

The terms of psychology comes from ancient Greek, psyche, that means all things relating to the soul. Meanwhile, according to Crow, psychology is the study of behavior, feelings, thoughts and actions of man in doing something (Crow, 1981:249). In literature, each character must have the interests and problems, and because of the importance and existence of the problem, there is interaction among characters. From the interaction that happens, readers can see to each character's characterization. What does each character do, talk, and thought is a reflection of the soul of each character (Darma, 2004:129).

According to the description above, in writing a work of literature, the author may not know or realize that through the interaction among the characters in his works, actually he has revealed a mental problems. The reader, by contrast, can sense the presence of mental problems covered in the literature. That is why literature can become an important source for psychiatrists and 
psychologists to give birth to their psychological theory (Darma, 2004:130).

Some reasons why psychology comes into literary studies are; 1) to study the behavior and motivations of characters in literature, 2) to study the behavior and motivation of the author, 3 ) to assess the psychological reactions of readers (Darma, 2004:138). The study of literature in this paper uses psychological approach to reveal the main character, Tokusuke Utsugi, behavior and motivation, in Diary of a Mad Old Man by Junichiro Tanizaki. It is in accordance with what Darma said above that one reason why psychology comes into literary studies, that is to study the behavior and motivations of the characters in literary works.

\section{Sexual Masochism}

The word 'masochism' was taken from the name of an Austrian novelist in the 19th century named Leopold von Sacher-Masoch, which in writing his novels often use the figure who has an obsession with sex that is combined with torture. Masochism is sexual pleasure obtained if the patient is physically injured, threatened or abused. The most severe masochism level can result in injury, either physical or psychological suffering, even death. There are two kinds of masochism; masochism with sexual motivation is called 'sexual masochism' and masochism without sexual motivation.

The Diagnostic and Statistical Manual of Mental Disorders, or better known as the DSM, is used by mental health professionals to diagnose mental disorder. In DSM-IV-TR 'the Fourth Edition Text Revision' mentioned that sexual masochism is one type of paraphilia. Paraphilia itself implies a very large of sexual desire arise through fantasy, sexual urges and behaviors. Sexual masochism is one type of paraphilia which is suffered by men because only five percent of sufferers are female masochism (www.medicstore.com).

In this discussion, the author uses the concept of sexual masochism described by George R. Brown in www.medicstore.com. According to Brown, a characteristic of sexual masochism is the feeling of pleasure and sexual arousal caused by pain, either physical or psychological (humiliation) conducted by their sex partners to arouse sexual excitement. Brown stated that the emergence of sexual masochism due to sexual fantasies on hold. This means the result of the sexual desires are not channeled, so, the desire to deliver their sexual desire is channeled through a deviant sexual fantasy.

\section{Methodology}

Tokusuki Utsugi's sexual masochism in Junichiro Tanizaki's Diary of a Mad Old Man will be analyzed using descriptive qualitative methods. All data collected through literature review. The data obtained were classified into two groups; the main data and additional data. The main data is the original novel of Diary of a Mad Old Man by Junichiro Tanizaki published by Alfred. Knof, Inc, Japan. Additional data obtained from several related articles and books that support the analysis of this novel.

\section{The Symptoms of Sexual Masochism Experienced by Tokusuki Utsugi}

Based on the theory of sexual masochism expressed by Brown, the symptoms of the sexual masochism experienced by Tokusuke Utsugi can be described as follows:

First: Tokusuke Utsugi's sexual desire resulting from torture or acceptance of pain from satsuko

Mentioned in the story that Tokusuke Utsugi is a grandfather of seven-seven-year-old who can only find sexual arousal if subjected to torture by a woman who has a bad temper and rough. Tokusuke Utsugi also realized his sexual disorder that tends to love a woman like that than women who have a good temperament and can give him affection. This was demonstrated by excerpts below.

"It's odd, but even when I am in pain I have a sexual urge. Perhaps especially when I am in pain. Or should I say that I am more attracted, more fascinated by women who cause me pain?" (Tanizaki, 1996:26).

For him, a good woman is not on how much she has meaning in his life, this agrees with what is stated in the quotation above, which states that the woman who caused him to suffer considered more attractive. In addition, for Utsugi, a cruel woman, who is full of resentment, envy or jealousy, was something that could make she seem other than her beauty. He had not thought about the consequences of poorly received if he was dealing with a woman like that, but otherwise he's going to get fun because this is one way for him to obtain his sexual gratification. His admiration for the woman with a bad temper was emphasized through the following quote.

'Suppose there are two women equally beautiful, equally pleasing to his aesthetic tastes. $A$ is kind and honest, and sympathetic; $B$ is unkind, a clever 
liar. If you ask which would be more attractive to me, I'm quite sure that these days I would prefer $B$. However it won't do unless $B$ is at least the equal of $A$ in beauty" ...... and I would be more susceptible to the woman with bad character: "... but if I found a woman who was really bad, and if I could live with her - or at least live in her presence, on intimate terms with her - how happy I would be!". (Tanizaki, 1996:27)

Based on the above quotation, to satisfy his sexual drive, Tokusuke Utsugi trying to seduce his daughter-in-law named Satsuko. He chooses Satsuko because apart of her beauty, she is a woman who has the character he expected all along, that is the women with a bad temper that can bring Utsugi to his sexual desires. It was emphasized through the following quote.

Does my love for satsuko come from my impression that there is something Oden in her? She is a bit spiteful. A bit sarcastic. And she is a bit of liar....she doesn't get along very well with her mother-in law or sister-in-law. She's cold toward her chid....No doubt that is because she realizes how much her behavior pleases me....the more spiteful she is, to them the more she fascinates me. (Tanizaki,1996:29)

In the above quotation, it can be seen that Satsuko is onsidered by Tokusuke Utsugi as a woman who likes to talk rude, spiteful, never to be tender toward his children, and she is wild. Because of her bad behavior, she was not well liked by the wife of Tokusuke Utsugi and that is the main thing that often makes them fight. But Satsuko's bad traits and so rude treatment to him sometimes makes he more fascinated by her. Some of Satsuko's characters impressed him reminded of the famous killer of a woman named Takahashi Oden. In addition, some sections of the novel show some form of physical torture by Satsuko when he was in hospital with Tokusuke Utsugi. Utsugi take a hit from Satsuko when he was about to ask for a kiss from him. "I'll hit you again! I mean it! Last time you onlygot a little tap." My hand can sting! If I really hit you, you'll see stars!"But that's what I'd like." (Tanizaki, 1996:50). Because he has a tendency to like torture, then Tokusuke Utsugi interpreted this as a pleasure for him.

Second: Tokusuke Utsugi's sexual desire resulting from suffering due to his various illness

The next symptoms of sexual masochism experienced by Tokusuki Utsugi is sexual desire resulting from suffering due to his various illness itself. He realizes that one way of getting sexual pleasure was when he is forged by an extraordinary pain due to his illness. Because of that, he often fantasized or even does an activity that will ultimately make the pain relapse. It can be exemplified when he kissed the feet of Satsuko in the bathroom. Every time he does, he gets a great pain because his blood pressure rose dramatically. But it had an impact of extraordinary pleasure for him. "His sexual activities with Satsuko often make his high blood pressure and it potentially endangers his health and life." (Tanizaki, 1996:48). From this case, it appears that Tokusuke Utsugi get pain and great pleasure simultaneously. When he felt it growing pains, it also increases the pleasure which he enjoyed. Tokusuke Utsugi willing to get a tremendous pain, he's even willing to sacrifice his life just to get his sexual satisfaction.

Third: Tokusuke Utsugi's sexual desire resulting from the insult he received from satsuko

The tendency of Tokusuke Utsugi to experience sexual masochism can be seen from the emergence of his sexual desire caused by the various insults from Satsuko spoken to him. For Tokusuke Utsugi, insult is one way of getting sexual satisfaction indirectly. Gaining sexual satisfaction for him is not only from physical abuse but also mental abuse. This is evidenced through the novel excerpt below.

As a masochist, Utsugi also enjoys being humiliated or hurt psychologically. The pain, suffering, or humiliation is real and can be psychological in nature. He doesn't mind being cheated by Satsuko (Tanizaki, 1996:29).

From the quotation above, it can be seen that the insult (psychological torment for him) would not make Tokusuke Utsugi angry or offended, but it is one way to bring up his sexual desires. Satsuko repeatedly insulted him by saying that he is very ugly, stupid and a liar old man; but the more he was insulted by his love, Satsuko, then his love was growing so big. This is evidenced through the passage below.

"See! She held the mirror up to my face, "well? What do you think? It's incredibly ugly." (Tanizaki, 1996:101)

"Listen Satsuko, from now on let me call you Satsu' sometimes!'.

'silly!'.

'Satsu.' 
You're a spoiled deceitful child' (Tanizaki, 1996:114)

\section{The Causal Factors of Tokusuke Utsugi's Sexual masochism}

One of the emerging tend of sexual masochism suffered by Tokusuke Utsugi is due to his inability to channel his sexual desires that are too big to perform sexual activities as most normal people. He knows that he is impotent, so with that condition, he is only able to channel his sexual desires through his sexual fantasies with someone who can make him feel sick because the suffering that he is experienced is considered by him as one way to satisfy his sexual desires. This is evidenced through the novel excerpt below.

"it seems to have some connection with the sex of an impotent old man- even if you're impotent you have a kind of sex life..." (Tanizaki, 1996:5).

"...Is it possible that physical suffering, that inability to enjoy the normal pleasures of sex, could distort a man's outlook this much?" (Tanizaki, 1996:29).

In the above quotation, it can be known how he channeled his huge sexual desires with make an imagination about deviant sexual behavior. So, it can stated that the tendency of Tokusuke Utsugi be a 'sexual masochist' is the result of the detention or burial deviant sexual desire caused by he is impotence and he have not found anyone who can give him the satisfaction. So when he met Satsuko, the woman who he thinks can give him sexual satisfaction, he becomes submitted to her.

\section{The Results of Sexual Masochism Experienced by Tokusuke Utsugi}

As mentioned in the novel, that sexual masochism experienced by Tokusuke Utsugi has many impacts. The impact posed by his sexual masochism orients him to be an old man who is insane 'the mad old man'. It can be proved by the statements and quotations in the novel as evidence of his insanity.

\section{First: The tendency for emphasizing Satsuko's sake than the sake of him and his family}

Because Tokusuke Utsugi prefer women with a bad temperament, then he prefer Satsuko than his own wife. In any case, he would be more concerned to Satsuko. Tokusuke Utsugi dare to do anything that will make Satsuko happy even if it sacrificed himself, his children or his wife. This is shown by Tokusuke Utsugi when he chooses Satsuko to accompany him when he was in the hospital than accompanied by his own wife. In fact, the presence of Satsuko having smoking is very harmful for him, but it does not matter as long as he still could be with Satsuko.

Second, Tokusuke Utsugi will still defend Satsuko's opinion although her opinion was opposed by many people. Like when his wife was at loggerheads with Satsuko about bathroom renovations, despite the opinion of his wife that 'bath tub' in the bathroom made out of wood because it would not harm, but he prefers the opinion of Satsuko who prefer the bathroom floor and 'bath tub' is made of ceramic material. Even though in a few times it harm himself and his wife, he's not regret or feel guilty to his wife.

In addition, Tokusuke Utsugi even willing to do anything for the sake of Satsuko. He is willing to fulfill what Satsuko want although it is not reasonable. Tokusuke Utsugi known miserly, prefer to buy Satsuko diamond whose price was fantastic than to meet the needs of his family to renovate the house, 'You're pretty good, Aunt Satsuko. Getting part withh Grandfather to three million yen '(Tanizaki, 1996:140).

\section{Second: The tendency of Tokusuke Utsugi doing crazy things}

Sexual masochism experienced by Tokusuke Utsugi certainly made him more correct to say as an old crazy man 'the mad old man'. One of the crazy things that is resulted from the fulfillment of his deviant sexual arousal is making his gravestones that were given symbol the stamp of Satsuko's feet. This was done because he'll feel his desire is fulfilled and can die in peace only with the stamp of the foot of the beautiful woman who has a bad character, Satsuko, who he had been loved.

'Nothing could be better than to be lie buried under her image'.

'Iwant to "I intend to have a Buddha's Footprint Stone carved on the model of your feet, Satsu. When I'm dead my ashes will lie under that stone. That will be my Nirvana." (Tanizaki, 1996: 153).

In his life, Tokusuke Utsugi loved Satsuko and willing to do anything for her, even when he dies, he has desire to always be accompanied by Satsuko. He hopes that by putting Satsuko's foot prints above his grave stones, the cemetery was becoming a heaven for him.

"At the very thought of those Buddha's Footprints after her own feet she would hear my bones wailing under the stone. Between sobs I would 
scream: 'It hurts! It hurts!... Even though it hurts, I'm happy- I've never been more happy, I'm much, much happier than when I was alive!... Trample harder! Harder!" (Tanizaki, 1996:155)

In the quotation above, it can be affirmed that Tokusuke Utsugi imagine the future if he dies then the Satsuko's footprints in his gravestone would oppress and trample on him. With the tendency of sexual masochism, of course, it is an extraordinary pleasure for him.

\section{Conclusion}

Based on the notice and the facts above, it can be concluded that Tokusuke Utsugi was a 'sexual masochist "i.e. people who have sexual deviations with the symptoms experienced are: 1) sexual desire resulting from torture or acceptance of pain from Satsuko, 2) sexual desire resulting from suffering due to the various illnesses he suffered, and 3) sexual desire resulting from insult or humiliation he received from Satsuko.

Sexual masochism suffered by Tokusuke Utsugi is the result of burial his deviant sexual fantasies. As a result of the fulfillment of a deviant sexual desire, he was willing to do crazy things. He was willing to meet any desired by a woman who can fulfill his sexual desires, Satsuko, although it was sacrificing himself and his family.

\section{REFERENCES}

Crow, Lester D. and Crow, Alice. 1981. General Psychology. Revised Edition. USA: Littlefield, Adams \& CO.

Darma, Budi. 2004. Pengantar Teori Sastra. Jakarta: Pusat Bahasa, Depdiknas

George, R. Brown. 2008. "Sexual Masochism". Accessed at http://www.medicstore.com from December 12 th.

Tanizaki, Junichiro. 1996. Diary of a Mad Old Man. Japan: Alfred. Knof, Inc. 